\title{
Pengaruh penambahan tepung daun Indigofera (Indigofera zollingeriana) dalam pakan terhadap kandungan kimia telur ayam arab
}

\section{The effect of addition of Indigofera leaf flour(Indigofera zollingeriana) in the feed on the chemical quality of arabic chicken eggs}

\author{
Asis Surajat $^{1 *}$ dan Anita Mustika Ibrahim ${ }^{1}$ \\ ${ }^{1}$ Program Studi Peternakan Universitas Muslim Buton. Jln. Betoambari Nomor 146, Kota Baubau, Sulawesi \\ Tenggara \\ *Email Koresponden: asissurajat@umubuton.ac.id
}

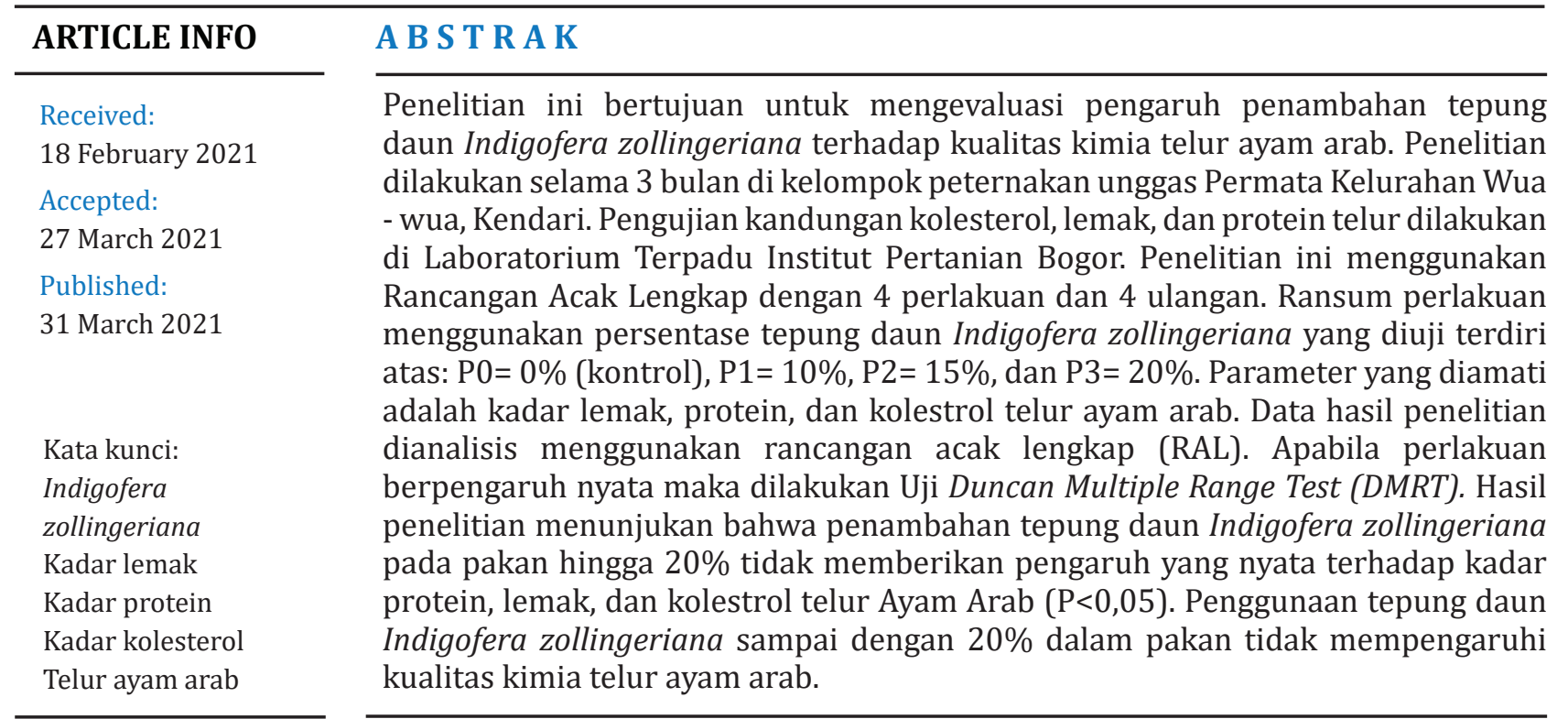

\section{A B S T R A C T}

The aim of this research to study the effect of Indigofera zollingeriana leaf meal on the chemical quality of Arabian chicken eggs. The research was conducted for 3 months at the Permata poultry farm group, Wua - wua Village, Kendari. The analysis of protein, fat, and cholesterol content of Arabic chicken eggs was carried out at the Integrated Laboratory of the Institut Pertanian Bogor. The study used a completely randomized design (CRD) with 4 treatments and 4 replications. Experimental rations using the percentage of Indigofera zollingeriana leafflour, such as: $P 0=0 \%, P 1=10 \%, P 2=15 \%$, and P3= 20\% Indigofera leaf flour zollingeriana. The parameters observed were levels

Key words:

Indigofera of protein, fat, and cholesterol level in Arabic chicken eggs. The research data used a completely randomized design (CRD), if the analysis had a real effect, carried out with the Duncan Multiple Range Test (DMRT). The results showed that the addition

Fat content

Protein content

Cholesterol levels of Indigofera zollingeriana leaf on rations up to $20 \%$ did not have a significant effect on protein, fat, and cholesterol level of Arabic chicken eggs $(P<0.05)$. Using Indigofera zollingeriana leaf meal up to $20 \%$ in rations does not affect the chemical quality of Arabian chicken eggs.

\section{PENDAHULUAN}

Ayam arab merupakan salah satu jenis ayam petelur bukan ras yang memiliki prospek pasar yang baik untuk dikembangkan dan produksi telur relatif tinggi. Produksi telur ayam arab relatif mendekati produktivitas ayam ras petelur, yaitu sekitar $28,63 \pm 0,76$ butir perbulan serta kandungan protein 18,74\% (Yumna, Zakaria, \& Nurgiartiningsih, 2014). 
Kandungan kimia telur ayam arab yang baik dapat dicapai ketika kebutuhan nutrien dalam pakan tercukupi. Pakan ayam arab yang baik merupakan pakan yang memiliki kandungan nutrien yang sesuai dengan kebutuhan ayam arab untuk pertumbuhan dan produksi. Kandungan kimia telur ayam arab dipengaruhi oleh bahan pakan yang diberikan. Bahan pakan yang baik dapat meningkatkan produktivitas dan kualitas kimia telur ayam arab. Salah satu bahan pakan yang memiliki kandungan nutrien yang baik yaitu daun Indigofera zollingeriana.

Tanaman Indigofera zollingeriana merupakan hijauan yang memiliki produktivitas cukup tinggi dan kandungan proteinnya yang cukup tinggi. Menurut Abdullah (2014) kadar protein kasar daun Indigofera zollingeriana 29,16 $\%$, serat kasar 14,02 \%, dan lemak kasar 3,62 \%. Pemberian daun Indigofera zollingeriana pada pakan dapat menurunkan kandungan kolesterol telur puyuh, kandungan malondyaldehide serta ß-karoten tepung pucuk Indigofera zollingeriana tergolong tinggi, mencapai 507,6 mg/kg sehingga dapat meningkatkan kandungan vitamin A telur burung puyuh (Faradillah, 2015). Dilihat dari kandungan nutrien dan fungsinya, daun Indigofera zollingeriana dapat digunakan sebagai bahan pakan. unggas. Berdasarkan alasan tersebut maka dilakukan dengan melakukan penelitian penambahan tepung daun Indigofera zollingeriana dalam pakan ayam arab untuk mengetahui pengaruhnya terhadap kualitas kimia telur ayam arab.

\section{MATERI DAN METODE}

Penelitian ini dilakukan selama 3 bulan. Pemeliharaan ayam arab dilakukan di Lokasi Kelompok Peternakan Unggas Permata Kelurahan
Wua - wua, Kendari. Analisis kandungan kolestrol, lemak, dan protein telur ayam arab dilakukan di Laboratorium Terpadu Institut Pertanian Bogor.

Penelitian ini menggunakan 32 butir telur ayam arab yang dihasilkan dari ayam arab betina berumur 6 bulan, rata-rata berat ayam 1,10 $\mathrm{kg} \pm$ 0,05 . Alat yang digunakan pada penelitian adalah peralatan laboratorium untuk menganalisis kandungan kimia telur ayam arab.

\section{Pakan Perlakuan}

\section{a. Pembuatan tepung daun Indigofera zollingeriana \\ Pembuatan tepung daun Indigofera} zollingeriana dilakukan dengan beberapa tahap: daun Indigofera zollingeriana segar, yang digunakan adalah bagian daun yang masih muda, selanjutnya daun diangin-anginkan tetapi tidak terkena matahari secara langsung selama kurang lebih1 hari agar daun tidak berubah warna. Setelah diangin-anginkan daun dijemur dengan cahaya matahari selama kurang lebih 10 jam, kemudian digiling hingga berbentuk tepung.

\section{b. Analisis kandungan nutrien bahan pakan}

Analisis kandungan nutrien tepung daun Indigofera zollingeriana, dedak padi, jagung giling, dan konsentrat dilakukan di Laboratorium Ilmu Nutrisi dan Teknologi Pakan Institut Pertanian Bogor.

\section{c. Komposisi bahan dan kandungan nutrien pakan perlakuan}

Komposisi nutrien bahan pakan yang digunakan pada penelitian ini disajikan pada Tabel 1 dan persentase pemberian beberapa jenis bahan pakan dan kandungan nutriennya dapat dilihat pada Tabel 2 .

Tabel 1. Komposisi nutrien bahan pakan penelitian.

\begin{tabular}{lcccc}
\hline \multirow{2}{*}{ Bahan pakan } & \multicolumn{4}{c}{ Kandungan nutrien bahan pakan } \\
\cline { 2 - 5 } & Protein kasar (\%) & Lemak (\%) & $\begin{array}{c}\text { Energi metabolis } \\
\text { (kkal/kg) }\end{array}$ & Serat kasar (\%) \\
\hline Indigofera & 25,66 & 3,78 & 2.900 & 12,15 \\
Dedak & 11,2 & 13,51 & 2.400 & 10,44 \\
Jagung & 8,5 & 2,32 & 3.300 & 8,82 \\
RK-24 & 28,25 & 2,39 & 3.500 & 8,43 \\
\hline
\end{tabular}

Keterangan: Komposisi nutrien bahan pakan daun Indigofera, jagung, RK-24 dan dedak hasil analisis Laboratorium Ilmu dan Teknologi Pakan IPB 
Tabel 2. Persentase dan kandungan nutrien bahan pakan penelitian.

\begin{tabular}{lcccc}
\hline \multirow{2}{*}{$\quad$ Bahan pakan } & \multicolumn{3}{c}{ Perlakuan } \\
\cline { 2 - 5 } & P0 & P1 & P2 & P3 \\
\hline Jagung (\%) & 19 & 22 & 24 & 25,7 \\
Dedak (\%) & 38,1 & 33,1 & 30 & 27,3 \\
Kosentrat(\%) & 42,9 & 34,9 & 31 & 27 \\
Tepung daun indigofera (\%) & 0 & 10 & 15 & 20 \\
Total (\%) & 100 & 100 & 100 & 100 \\
Kandungan nutrien : & & & 18 \\
Protein Kasar (\%) & 18 & 18 & 5,91 & 18 \\
Lemak (\%) & 6,61 & 6,19 & 5,69 \\
Energi Metabolis (kkal/kg) & 3042,9 & 3031,9 & 3032 & 3028,3 \\
Serat Kasar (\%) & 9,27 & 9,55 & 9,68 & 9,82 \\
\hline
\end{tabular}

Keterangan: Metode penyusunan ransum perlakuan menggunakan metode trial and error.

\section{d. Pemberian pakan perlakuan}

Pemberian pakan perlakuan dilakukan selama 35 hari. Pakan diberikan sesuai dengan kebutuhan pakan Ayam Arab.

\section{e. Pengambilan data dan sampel}

Evaluasi kandungan kimia telur Ayam Arab dilakukan pada minggu keempat setelah diberikan pakan perlakuan. Telur yang diamati adalah telur yang dihasilkan seminggu terakhir pada minggu keempat perlakuan. Penelitian dilakukan selama 3 bulan. Penentuan sampel telur yang dianalisis dilakukan secara acak.

\section{Rancangan Penelitian}

Penelitian ini menggunakan Rancangan Acak Lengkap (RAL) pola searah. Ransum percobaan yang diuji adalah sebagai berikut:

$\mathrm{P0}=$ Ransum mengandung 0\% Tepung daun Indigofera zollingeriana.

$\mathrm{P} 1$ = Ransum mengandung 10\% Tepung daun Indigofera zollingeriana.

P2 = Ransum mengandung 15\% Tepung daun Indigofera zollingeriana.

P3 = Ransum mengandung 20\% Tepung daun Indigofera zollingeriana.

\section{Variabel Penelitian} adalah:

Variabel yang diamati pada penelitian ini

1. Kadar lemak, dilakukan analisis kadar lemak dengan metode sokhlet (AOAC, 2005).

2. Kadar protein, dilakukan dengan menggunakan metode mikro-Kjeldahl (AOAC, 2005).

3. Kadar kolestrol, dilakukan dengan menggunakan metode Liebermann Burchard (AOAC, 2005).

\section{Analisis Data}

Data hasil penelitian dianalisis menggunakan analisis ragam dengan rancangan acak lengkap (RAL) menggunakan software Statistical Product and Service Solutions (SPSS), jika terdapat perbedaan nilai rataan, maka dilakukan uji lanjut menggunakan Uji Duncan Multiple Range Test (DMRT), untuk mengevaluasi perbedaan antar perlakuan.

\section{HASIL DAN PEMBAHASAN}

\section{Kadar Lemak Telur}

Rataan kadar lemak telur ayam arab yang diberi perlakuan pakan mengandung tepung daun Indigofera zollingeriana disajikan pada Tabel 3.

Pemberian tepung daun Indigofera zollingeriana sampai dengan taraf $20 \%$ pada pakan tidak berpengaruh $(\mathrm{P}>0,05)$ terhadap kadar lemak telur ayam arab. Tidak berpengaruhnya kadar lemak telur ayam arab kemungkinan dipengaruhi oleh kandungan lemak yang dihasilkan oleh tepung daun Indigofera zollingerian yang rendah. Abdullah (2014) melaporkan bahwa kandungan lemak tepung daun Indigofera zollingeriana mencapai 3,62 \%. Penambahan tepung daun 
Indigofera zollingeriana pada pakan ayam arab dengan jumlah yang banyak, akan menurunkan kadar lemak dalam telur ayam arab.

\section{Kadar Protein Telur}

Kadar protein telur ayam arab yang diberi perlakuan pakan mengandung tepung daun Indigofera zollingeriana disajikan pada Tabel 3 . Pemberian tepung daun Indigofera zollingeriana pada pakan tidak berpengaruh $(\mathrm{P}>0,05)$ terhadap kadar protein telur ayam arab. Hal ini disebabkan kandungan protein ransum yang diberikan pada ayam arab hanya dimanfaatkan oleh jaringan tubuh ayam arab dan tidak dimanfaatkan sebagai pembentukan protein telur ayam arab. Pernyataan tersebut didukung oleh (Guyton, 1999) bahwa terdapat batasan jumlah protein yang dapat tertimbun didalam setiap sel, sehingga bila sel telah mencapai batas tersebut setiap penambahan asam amino akan dipecahkan dan digunakan untuk energi, disimpan dalam bentuk lemak dan dikeluarkan dalam bentuk amoniak.

Scott., Nesheim, \& Young (1982) menyatakan bahwa ayam arab kurang responsif terhadap perubahan taraf protein yang lebih tinggi dari $12 \%$. Kandungan asam amino dalam bahan pakan tidak memenuhi jumlah yang dibutuhkan, baik salah satu atau beberapa asam amino esensial maka akan mempengaruhi fungsi protein dalam tubuh. Fungsi protein dan asam amino yaitu pembentuk enzim, pembentuk bagian tubuh seperti bulu, sperma pada pejantan dan kuning telur pada betina, pengikat mineral tertentu, untuk transportasi dan penyimpanan unsur-unsur mineral keseluruh tubuh serta digunakan sebagai sumber energi (Yamamoto,. Juneja, Hatta, 2007).

\section{Kadar Kolesterol Telur}

Kadar kolesterol telur ayam arab yang diberi perlakuan pakan mengandung tepung daun Indigofera zollingeriana disajikan pada
Tabel 3. Pemberian tepung daun Indigofera zollingeriana pada pakan tidak berpengaruh $(\mathrm{P}>0,05)$ terhadap kadar kolesterol telur Ayam Arab. Tidak berpengaruhnya kadar kolesterol telur ayam arab dengan pemberian tepung daun Indigofera zollingeriana sampai taraf $20 \%$ diduga disebabkan kandungan lemak pada tepung daun Indigofera zollingeriana tergolong rendah.

Peningkatan kolesterol dapat terjadi dengan meningkatnya konsumsi lemak kasar dari ransum. Kolesterol dan asam lemak yang terbentuk di hati akan dibawa keseluruh tubuh dalam bentuk lipoprotein, asam lemak di hati akan diresintesis menjadi trigliserida kemudian bergabung dengan kolesterol, fospolipid dan protein menjadi very low density lipoprotein (VLDL) dan diangkut ke seluruh jaringan termasuk ke folikel ovarium (Stryer, 2000).

Lemak yang dikonsumsi berupa trigliserida akan terhidrolisis menjadi monogliserida, asam lemak bebas, dan gliserol di dalam sistem pencernaan. Asam lemak bebas kemudian akan mengalami re-esterifikasi dalam sel usus sebelum ditransfer ke dalam darah (Irianti, Tugiyanti, dan Yuwono, 2011). Asam lemak yang mengalami esterifikasi akan membentuk trigliserida, kolesterol dan ester kolesteril, sedangkan asam lemak yang tidak mengalami esterifikasi akan membentuk asam lemak bebas, dan ditemukan dalam kombinasi dengan albumin serum pada konsentrasi yang bervariasi antara $0,1 \mu \mathrm{eq} / \mathrm{mL}$ dan $0,2 \mu \mathrm{eq} / \mathrm{mL}$ plasma dan mencakup asam lemak rantai panjang yang ditemukan di dalam jaringan adiposa yaitu asam palmitat, stearat, oleat, palmitoleat, linoleat dan asam jenuh rantai panjang lainnya (Martin et al. 1987).

Peningkatan kadar kolesterol kuning telur juga dapat terjadi karena pembentukan kolesterol secara endogen karena kolesterol sangat dibutuhkan pada puyuh petelur dalam jumlah banyak untuk membentuk hormon steroid (Aviati, Mardiati, \& Saraswati, 2014).

Tabel 3. Kadar lemak, protein, dan kolesterol telur ayam arab yang diberi penambahan tepung daun Indigofera pada pakan.

\begin{tabular}{lcccc}
\hline \multirow{2}{*}{ Kadar kimia } & \multicolumn{4}{c}{ Perlakuan } \\
\cline { 2 - 5 } & P0 & P1 & P2 & P3 \\
\hline Kadar Lemak & $13,80 \pm 1,73$ & $13,35 \pm 1,15$ & $13,33 \pm 0,70$ & $12,91 \pm 1,17$ \\
Kadar Protein & $15,06 \pm 1,89$ & $14,56 \pm 1,25$ & $14,54 \pm 0,77$ & $14,08 \pm 1,28$ \\
Kadar Kolesterol & $6,27 \pm 0,79$ & $5,57 \pm 0,06$ & $6,06 \pm 0,32$ & $5,87 \pm 0,53$ \\
\hline
\end{tabular}


Pengangkutan asam lemak dan kolesterol dari hati ke seluruh tubuh dalam bentuk lipoprotein (endogenus), kemudian di hati, asam lemak diresintesis menjadi trigliserida yang kemudian bergabung dengan kolesterol, posfolipid, dan protein menjadi very low density lipoprotein (VLDL) yang akan diangkut ke seluruh jaringan tubuh termasuk ke folikel ovarium, sehingga dengan adanya peningkatan kolesterol endogen dan salah satunya tersalur ke folikel ovarium akan menjadikan kadar kolesterol telur lebih tinggi.

\section{KESIMPULAN}

Penambahan tepung daun Indigofera zollingeriana dalam pakan hingga 20\% tidak berpengaruh terhadap kadar lemak, kadar protein, dan kadar kolesterol telur ayam arab. Kandungan nutrien pada tepung daun Indigofera zollingeriana belum dapat dimanfaatkan secara maksimal untuk meningkatkan kualitas kimia dari telur ayam arab.

\section{DAFTAR PUSTAKA}

Abdullah, L. (2014). Prospektif Agronomi dan Ekofisiologi Indigofera zollingeriana sebagai Tanaman Penghasil Hijauan Pakan Berkualitas Tinggi. Pastura: Journal of Tropical Forage Science, 3(2), 79-83. https://doi.org/10.24843/Pastura.2014. v03.i02.p06

AOAC (Association of Official Analitycal Chemist). (2005). Official Methods of Analysis. Airlington. Virginia.
Aviati, V., Mardiati, S. M., \& Saraswati, T. R. (2014). Kadar Kolesterol Telur Puyuh Setelah Pemberian Tepung Kunyit dalam Pakan. Buletin Anatomi Dan Fisiologi, 22(1), 58-64.

Bell, D., \& Weaver, G. (2002). Commercial Chicken Meat and Egg. United States of America: Kluwer Academic Publishers.

Faradillah, F. 2015. Penggunaan tepung pucuk Indigofera zollingeriana sebagai substitusi bungkil kedelai dalam ransum terhadap produktivitas dan aspek kesehatan puyuh. Pascasarjana Institut Pertanian Bogor. Bogor.

Guyton A.C. (1999). TextbookofMedical Physiology. Philadelphia: W.B. Saunders Company.

Irianti, N., Tugiyanti, E., dan Yuwono. E. (2011). Pengembangan pakan fungsional pada pakan ayam kampung. Laporan Penelitian. Fakultas Peternakan Universitas Jenderal Soedirman. Purwokerto.

Martin, D.W., A.M. Peter., D.K. Granner and V.W. Rodwell. 1987. Biokimia Harper Edisi 20. (Terjemahan oleh Iyan Darmawan). EGC. Jakarta. Hal : 216-306.

Scott M.L., Nesheim, M. C., \& Young, R. J. (1982). Nutrition of the Chickens. Ithaca, New York.: M.L. Scott and Assoc.

Stryer L. (2000). Biokimia. penerjemah; Zahir SS, Setiadi E. Jakarta: Buku Kedokteran EGC.

Yamamoto, T., L.R. Juneja, H. Hatta, and M. K. (2007). Hen Eggs: Basic and Applied Science. Canada: University of Alberta.

Yumna, M. H., Zakaria, A., \& Nurgiartiningsih, V. M. A. (2014). Kuantitas dan kualitas telur ayam arab (Gallus turcicus) silver dan gold. Jurnal Ilmu-Ilmu Peternakan (Indonesian Journal of Animal Science), 23(2), 19-24. Retrieved from http://jiip.ub.ac.id/ 